JURNAL ILMU POLITIK, Volume 9 Nomor 2, Oktober 2018

\title{
PERLUNYA REVITALISASI KEBIJAKAN JAMINAN KESEHATAN DI INDONESIA
}

\author{
Budi Setiyono, Universitas Diponegoro \\ Email: budisetiyono@undip.ac.id
}

\begin{abstract}
ABSTRAK
The article discusses the government's effort to build national health insurance. There are still many challenges to achieve the goal. Underlying the principle of universal coverage, since the early 2000, the Indonesian government has made an ambitious policy of National Health Insurance (Jaminan Kesehatan Nasional/JKN). Law No. 40/2004 on National Health Insurance System is a clear sign of the government's commitment to provide health for all. To support the implementation, the government established an implementing body under the legal umbrella of Law No. 24/2011 on Social Insurance Implementing Boody (Badan Penyelenggara Jaminan Sosial/BPJS) that consists of BPJS Kesehatan (family based health insurance) and BPJS Ketenagakerjaan (corporation based health insurance). National Health Insurance integrates social assistance system promoted by the state for the less capable citizen, that all the people could attain health care through JKN. However, crucial problem arises, especially related to the availability of fund and the other resources that BPJS always suffers from deficit. Therefore, revitalizing healt care policy is crucial to make sure that JKN policy is sustainable.

Keywords:Welfare System, Health Service, Health Insurance, BPJS Kesehatan
\end{abstract}

\section{LATAR BELAKANG}

Kesehatan adalah salah satu indikator penting bagi tercapainya kehidupan yang sejahtera bagi suatu masyarakat. Oleh karena itu, pelayanan kesehatan yang terjangkau secara universal bagi semua orang telah menjadi pilar utama dalam konsep negara kesejahteraan (welfare state). Hal ini dikarenakan hidup yang sehat merupakan kondisi dasar untuk hidup sejahtera, sehingga mendapatkan pelayanan kesehatan yang baik adalah merupakan kebutuhan pokok dan hak bagi semua warga negara. Akan tetapi, karena biaya kesehatan yang tinggi, tidak semua anggota masyarakat mampu memperoleh pelayanan kesehatan yang layak. Golongan miskin, terutama, tidak memiliki kemampuan untuk membayar biaya kesehatan sehingga mereka mengalami musibah ganda manakala sakit, dimana mereka tidak bisa segera memulihkan kesehatan dan tidak bisa memperoleh penghasilan.

Paper ini mendiskusikan tupaya yang dilakukan oleh pemerintah Indonesia dalam membangun sistem Jaminan Kesehatan Nasional. Paper didasarkan kepada riset yang dilakukan selama lima bulan (Juni-Oktober) pada tahun 2017. Simpulan penelitian yang dipaparkan dalam paper ini menunjukkan bahwa upaya pemerintah tersebut masih menghadapi berbagai kendala signifikan yang menghambat pengembangan jangkauan JKN secara modern dan menyeluruh. 
Di Indonesia, hampir setiap saat terdapat berita di banyak daerah tentang kasus pasien meninggal karena terlantar, ditahan karena tidak sanggup membayar, bahkan tidak diobati karena alasan ketiadaan uang untuk membiayai rumah sakit. ${ }^{24} \mathrm{Hal}$ ini seharusnya menyadarkan pemerintah bahwa banyak warga negara yang tidak memiliki perlindungan hidup karena tidak ada jaminan terhadap aspek kesehatan. Tidak dipungkiri memang kemampuan pemerintah untuk mensubsidi pelayanan kesehatan sangat terbatas. Sehingga tanpa sistem yang handal untuk menjamin pembiayaan pelayanan kesehatan, maka akan semakin banyak nyawa masyarakat terancam karena ketidakmampuan berobat. Terlebih lagi, kebutuhan biaya pelayanan kesehatan yang cenderung mengalami kenaikan dapat berpengaruh pada kemampuan daya beli kesehatan masyarakat, sehingga jika seseorang jatuh sakit maka penghasilannya bisa habis untuk membiayai pengobatannya dan sehingga hilang kesejahteraan minimum. $^{25}$

Pada level internasional, selama beberapa dekade terakhir, pelaksanaan konsep negara kesejahteraan (welfare state) telah memicu debat yang gegap gempita tentang bagaimana seharusnya peran negara dalam melindungi warga terhadap pasar. Baik di negara maju maupun berkembang, pemerintah pada satu sisi berusaha terus menyediakan jaminan kesehatan dan perlindungan sosial, pada sisi lain juga berusaha menanggapi tekanan fiskal yang berkaitan dengan implementasi sistem kesejahteraan mereka dengan bereksperimen melalui alternatif tata kelola baru seperti layanan yang diprivatisasi, pembayaran subsidi yang ditargetkan dan bersyarat, dan manfaat tambahan yang dikaitkan dengan kontribusi peserta. Meskipun inisiatif ini bertujuan untuk memastikan keberlanjutan skema perlindungan sosial seraya menahan pengeluaran dan meningkatkan efisiensi, kritikus mengkhawatirkan bahwa hal ini justru mendorong diferensiasi yang lebih besar dalam akses ke kesejahteraan, memperdalam ketidaksetaraan, dan mengikis konsep kesejahteraan sebagai hak kewarganegaraan.

24 Lihat https://www.indonesiaberita.com/2018/05/25/pasien-ditolak-rs-blk-bekasi-akhirnya-tutup-usia/, https://www.liputan6.com/news/ read/3090761/3-kisah-pilu-bayi-meninggal-setelah-ditolak-rumah-sakit, dan https://news.okezone.com/read/2018/02/01/340/1853262/ditolak-puskesmas-pasien-sekarat-dibawa-pakai-pikap -pengangkut-pasir.

CNBC Indonesia, $29 \quad$ April 2018, alamat: https://www.cnbcindonesia.com/lifestyle/20180429164515-33-12936/mahalnya-biaya-berobat-dari-jatuh-sakitbisa-jatuh-bangkrut

Tempo, 5 Januari 2017, alamat: https://seleb.tempo.co/read/832989/dalam-2-bulan-harta-yana-zein-terkuras-untuk-berobat

${ }^{25}$ Lihat misalnya analisis media dan liputan khusus CNBC tentang ancaman biaya pengobatan tinggi dapat menyebabkan kebangkrutan (https://www.cnbcindonesia.com/lifestyle/20180429164515-33-12936/mahalnya-biaya-berobat-dari-jatuh-sakitbisa-jatuh-bangkrut). Contoh dalam hal ini misalnya, kasus yang dialami oleh artis terkenal Yana Zein, dimana dalam jangka waktu 2 bulan hartanya habis untuk berobat kanker (https://seleb.tempo.co/read/832989/dalam-2-bulan-harta-yana-zein-terkuras-untuk-berobat) 


\section{POLITIKA}

JURNAL ILMU POLITIK, Volume 9 Nomor 2, Oktober 2018

Dengan mengikuti tren universal coverage, sejak awal tahun 2000, para pengambil kebijakan di Indonesia mengumumkan perubahan yang ambisius terhadap sistem asuransi kesehatan negara dalam mengejar cakupan universal dan adil dan distribusi ulang yang lebih besar. Hal ini dipengaruhi oleh adanya mobilisasi gerakan demokrasi akar rumput di Indonesia selama akhir 1990-an yang memberikan kesempatan penting untuk pembelajaran politik yang secara mendalam menginginkan perubahan progresif dalam perlindungan sosial (termasuk kesehatan). Untuk tingkat yang signifikan, para aktor solidaritas yang datang dari kelompok buruh, LSM dan aktivis demokrasi lain berhasil menekan pemerintah untuk membuat dan menyediakan sistem jaminan kesehatan yang adil dapat diandalkan oleh seluruh masyarakat.

Pada tahap awal, hasil gerakan tersebut mempengaruhi terjadinya amandeman Undang-Undang Dasar (UUD) 1945, pasca gerakan demokratisasi tahun 1998, yang kini dalam Pasal 28H (1) menyebutkan setiap orang berhak hidup sejahtera lahir dan batin, bertempat tinggal, dan mendapat lingkungan hidup yang baik dan sehat serta berhak memperoleh pelayanan kesehatan. Amanat ini mendorong revisi Undang-undang No. 23 tahun 1992, (yang direvisi dengan UU 36/2009) tentang kesehatan, juga menetapkan bahwa kesehatan adalah hak fundamental setiap individu. Oleh karena itu negara bertanggung jawab untuk mengatur agar hak hidup yang sehat bagi penduduknya terpenuhi. Untuk mewujudkan komitmen global dan konstitusi di atas, pemerintah berinisiatif membentuk suatu sistem jaminan kesehatan masyarakat melalui Jaminan Kesehatan Nasional (JKN) bagi kesehatan perorangan. Melalui jaminan kesehatan tersebut, maka terdapat mekanisme gotong royong sehingga keterbatasan akses dan kemampuan membayar (bagi kelompok miskin) akan dapat dibantu oleh kelompok masyarakat yang lebih mampu, sehingga status kesehatan diharapkan akan meningkat (WHO, 2017 dan Mukti, 2009).

Artikel ini akan membahas pelaksanaan dan pengembangan program JKN oleh pemerintah Indonesia. Tulisan akan didahului dengan menyajikan tinjauan teori tentang jaminan kesehatan dan social welfare, kebijakan jaminan kesehatan di Indonesia, mekanisme Jaminan Kesehatan Nasional, gambaran tentang skema sistem kolektif, serta mendiskusikan tentang tantangan keberlanjutan program JKN/KIS. Pada bagian akhir, artikel akan juga memberikan rekomendasi untuk revitalisasi penyempurnaan sistem tersebut di masa yang akan datang. 
JURNAL ILMU POLITIK, Volume 9 Nomor 2, Oktober 2018

\section{JAMINAN KESEHATAN DAN SOCIAL WELFARE: TINJAUAN TEORI}

Sampai abad kesembilan belas, di semua negara, perawatan medis pada dasarnya bersifat pribadi atau sukarela. Pelayanan kesehatan dilakukan di rumah tinggal masing-masing oleh praktisi kesehatan seperti tabib dan perawat. Namun, kesadaran bahwa penyakit adalah penyebab utama kemiskinan, menyebabkan otoritas negara mulai mengembangkan 'klinik' dan 'rumah sakit' untuk orang sakit. Jumlah rumah sakit kemudian tumbuh sangat pesat setelah pendidikan profesi dokter berkembang di universitas dan disertai keinginan banyak negara untuk menciptakan kesejahteraan universal bagi rakyatnya. Secara umum diterima bahwa faktor penentu kesehatan adalah meliputi pewarisan genetik, lingkungan fisik - alamiah dan bawaan — dan lingkungan sosial. Sejumlah besar penelitian menemukan keterkaitan antara lingkungan sosial dan kesehatan pada konteks integrasi sosial, jejaring sosial, dan dukungan sosial (Berkman \& Glass, 2000). Misalnya, kehilangan pekerjaan dan ancaman kehilangan pekerjaan memiliki dampak negatif pada kesehatan (Kasl \& Jones, 2000). Dampak dari faktor-faktor ini pada kesehatan dimediasi oleh respon individu terhadap mereka, baik perilaku maupun biologis (Evans and Stoddart, 1994). Dalam konteks tersebut, terdapat pula pemahaman bahwa kesehatan individu dan populasi ditentukan oleh salah satunya adalah adanya perawatan kesehatan (Jonas, dkk, 2007, hlm. 5-6).

Fokus utama perawatan kesehatan adalah memulihkan kesehatan atau mencegah eksaserbasi masalah kesehatan. Jika kita berpendapat bahwa kesehatan adalah produk dari banyak faktor termasuk warisan genetik, lingkungan fisik, dan lingkungan sosial, serta respon perilaku dan biologis individu terhadap faktor-faktor ini, kita melihat bahwa perawatan kesehatan memiliki dampak di akhir rantai kausal yang menyebabkan penyakit dan kecacatan. Sering kali pada saat individu berinteraksi dengan sistem perawatan kesehatan, faktor-faktor penentu kesehatan telah berdampak pada status kesehatan mereka, baik atau buruk. Dengan demikian, kebutuhan untuk perawatan kesehatan dapat dilihat sebagai kegagalan untuk mencegah faktor-faktor penentu kesehatan dari pengaruh negatif pada pasien individu.

Perawatan kesehatan, dengan demikian, dapat dikategorikan dalam hubungannya dengan pencegahan - primer, sekunder, dan tersier. Fos and Fine (2000) mendefinisikan istilah-istilah ini sebagai, "Pencegahan primer berkaitan dengan menghilangkan faktor-faktor risiko untuk suatu penyakit. Pencegahan sekunder berfokus pada deteksi dini dan pengobatan penyakit (subklinis dan klinis). Sedangkan upaya pencegahan tersier untuk menghilangkan atau cacat sedang terkait dengan penyakit lanjut" (Fos \& Fine, 2000, hlm. 108-109). 


\section{POLITIKA}

JURNAL ILMU POLITIK, Volume 9 Nomor 2, Oktober 2018

Pencegahan primer bermaksud untuk mencegah perkembangan penyakit atau cedera sebelum terjadi pada individu, dan dengan demikian mengurangi resiko terjadinya insiden penyakit dalam suatu populasi. Contohnya termasuk olah raga, penggunaan sabuk pengaman mobil, konsumsi makanan sehat bergizi, perlindungan kulit dari sinar ultraviolet, dan program penghentian penggunaan rokok. Pencegahan sekunder berkaitan dengan mengurangi beban penyakit yang ada setelah berkembang; deteksi dini ditekankan. Kegiatan pencegahan sekunder (seperti pemeriksaan rutin, cek laboratorium, dan konsultasi kesehatan) dimaksudkan untuk mengidentifikasi keberadaan penyakit secara dini sehingga perawatan dapat efektif dan bermanfaat untuk mencegah penurunan kualitas kesehatan. Pencegahan tersier berfokus pada perawatan optimal dari penyakit yang tampak jelas dan teridentifikasi secara klinis sehingga dapat mengurangi timbulnya komplikasi di kemudian hari ke tingkat yang semaksimal mungkin. Dalam kasus dimana penyakit telah dikaitkan dengan efek samping, pencegahan tersier melibatkan rehabilitasi dan pembatasan kecacatan.

Perawatan kesehatan terutama berkaitan dengan pencegahan sekunder dan tersier, meliputi deteksi dini, diagnosis, dan pengobatan kondisi yang dapat disembuhkan atau dibatasi dalam konsekuensinya (pencegahan sekunder); dan pengobatan kronis penyakit dan kondisi lain untuk mencegah eksaserbasi, menstabilkan kondisi, dan meminimalkan komplikasi masa depan (pencegahan tersier). Sistem perawatan kesehatan tidak diragukan lagi memiliki dampak terkecil pada pencegahan primer, yakni intervensi yang fokus pada menghentikan penyakit, dan cedera sebelum mereka mulai.

Sistem perawatan kesehatan memiliki lima komponen utama, yaitu fasilitas di mana perawatan kesehatan disediakan; tenaga kerja yang menyediakan layanan perawatan kesehatan; penyedia terapi perawatan kesehatan seperti farmasi dan peralatan medis; lembaga pendidikan dan penelitian yang melatih tenaga kerja perawatan kesehatan dan menghasilkan pengetahuan untuk meningkatkan layanan perawatan kesehatan, dan mekanisme pembiayaan-yang biasanya bisa berasal dari individu maupun asuransi jaminan kesehatan (Jonas, dkk, 2007, hlm. 8). Selain struktur organisasi ini, dalam sistem perawatan kesehatan negara manapun mungkin ada lokus kekuasaan dan kontrol lainnya yang menjadi pusat sistem. Mereka memungkinkan komponen sistem untuk berinteraksi dan berfungsi untuk menghasilkan layanan kesehatan bagi masyarakat (Jonas, 2007). Bentuk dan peran proporsional masing-masing berbeda di antara sistem nasional. Di Amerika Serikat, seperti di sebagian besar negara industri, ada lima jenis utama sektor layanan kesehatan, yaitu otoritas 
JURNAL ILMU POLITIK, Volume 9 Nomor 2, Oktober 2018

kesehatan pemerintah utama, lembaga pemerintah lainnya dengan fungsi perawatan kesehatan, sektor perawatan kesehatan swasta, perusahaan komersial lain di bidang kesehatan, dan agen perawatan kesehatan sukarela. Kesemua komponen ini bekerja dalam satu sistem yang terintegrasi.

Dalam konteks pembiayaan perawatan kesehatan, asuransi jaminan kesehatan merupakan komponen yang sangat vital untuk menjamin akses layanan kesehatan bagi masyarakat. Sebagaimana dikemukakan oleh laporan Committee on the Consequences of Uninsurance Board on Health Care Services (CCUBHCS, 2001, hlm. 6-10), asuransi kesehatan memiliki manfaat untuk berbagai konstituen dan tujuan yang berbeda. Untuk individu dan keluarga, perlindungan asuransi adalah salah satu sarana untuk meningkatkan kesehatan dan akses keperawatan dan untuk melindungi terhadap biaya perawatan kesehatan yang luar biasa. Asuransi melindungi dari biaya medis yang dapat mengganggu keuangan, membantu merencanakan ke depan atau menganggarkan untuk perawatan kesehatan.

Berbeda dengan banyak produk asuransi lain, seperti asuransi mobil atau pemilik rumah, asuransi kesehatan telah berevolusi sebagai mekanisme untuk membiayai pengeluaran perawatan kesehatan rutin dan mendorong penggunaan layanan pencegahan, selain untuk melindungi diri dari kejadian dan pengeluaran yang tidak biasa. Ruang lingkup dan efektivitas intervensi perawatan kesehatan telah tumbuh. Demikian juga dengan harapan konsumen untuk memperoleh manfaat melalui asuransi kesehatan. Bagi penyedia layanan kesehatan, mereka mendapat manfaat dari asuransi sebagai sumber pembayaran yang andal. Pada sisi lain, bagi pengusaha, asuransi kesehatan menawarkan manfaat kesehatan untuk menarik dan mempertahankan pekerja dan mempertahankan tenaga kerja yang produktif.

Oleh karena pentingnya asuransi jaminan kesehatan ini, maka pemerintah di banyak negara menyediakan asuransi kesehatan untuk populasi khusus sebagai sarana untuk mengamankan perawatan kesehatan bagi mereka. Semua negara-negara maju, khususnya yang tergabung dalam Organisation for Economic Co-operation and Development (OECD), secara khusus telah mengadopsi sistem welfare state, yang menyediakan skema jaminan sosial terpadu bagi rakyat mereka, termasuk perlindungan dalam jaminan layanan kesehatan atau Social Health Insurance (Asuransi Kesehatan Sosial--AKS) (CCUBHCS, 2001, hlm. 15; OECD, 2014). AKS adalah bentuk pembiayaan dan pengelolaan perawatan kesehatan berdasarkan penyatuan risiko, dengan mengumpulkan risiko biaya kesehatan dari seluruh penduduk, dengan kontribusi individu, rumah tangga, perusahaan, dan pemerintah, sehingga sering didefinisikan sebagai "a financial protection mechanism for health care, through health 


\section{POLITIKA}

JURNAL ILMU POLITIK, Volume 9 Nomor 2, Oktober 2018

risk sharing and fund pooling for a larger group of population" (WHO, 2003, hlm. 5).

Menurut pakar Bank Dunia, Gottret \& Schieber (2006, 74), AKS memiliki beberapa keuntungan. Pertama, asuransi kesehatan sosial dapat menjadi cara yang efektif untuk meningkatkan sumber daya tambahan bagi kesehatan dan untuk menjangkau cakupan universal. Secara khusus, dengan membuat pembiayaan perawatan kesehatan lebih transparan dan stabil, asuransi kesehatan sosial dapat mendorong penduduk untuk berkontribusi lebih banyak pada sistem cakupan kesehatan.

Dengan demikian, skema dalam mekanisme ini melindungi seluruh orang dalam suatu negara terhadap beban keuangan dan ancaman sakit dan merupakan metode yang relatif adil dalam pembiayaan perawatan kesehatan. Dengan AKS, biasanya hampir semua perawatan di rumah sakit gratis bersama dengan obat-obatan yang diberikan di rumah sakit, bahan habis pakai dan peralatan bedah yang dikeluarkan atau dipinjamkan. Peserta hanya membayar sebagian kecil biaya administrasi saja. Namun, jika pasien memilih untuk dirawat di rumah sakit menggunakan asuransi biaya pribadi, atau meminta layanan dengan standar kualitas lebih tinggi, pasien dapat menagih sebagian biaya tersebut ke lembaga AKS pemerintah.

Sebagian besar sistem jaminan kesehatan negara maju (seperti MedicAid di Amerika, NHS - National Health Service di Inggris, dan Medicare di Australia) sangat bergantung pada keuangan yang didanai pajak, sehingga pembiayaan AKS ini biasanya terkoneksi dengan sistem perpajakan (khususnya pajak penghasilan), walaupun ada juga beberapa negara yang mengaturnya secara terpisah. Oleh karena itu, kebijakan asuransi jaminan kesehatan memiliki keterkaitan yang erat juga dengan kebijakan pada sektor ketenagakerjaan dan fiskal. Sebaliknya, sebagian besar negara berkembang membiayai pengeluaran perawatan kesehatan masyarakat mereka dari sumber daya publik (pajak) yang sedikit sehingga ada beban yang tidak adil bagi orang miskin. Meskipun ada upaya untuk memberikan subsidi kepada orang miskin, seringkali ini gagal. Hal ini dapat dimengerti karena sebagian besar negara berkembang tidak memiliki pendapatan yang cukup dari perpajakan umum.

\section{KEBIJAKAN JAMINAN KESEHATAN DI INDONESIA}

Sejak masa orde baru, pemerintah Indonesia sesungguhnya telah merintis penyelenggaraan beberapa bentuk jaminan sosial di bidang kesehatan, diantaranya adalah melalui PT Askes (Persero), PT. Asabri, dan PT Jamsostek (Persero) yang melayani antara lain pegawai negeri sipil, penerima pensiun, tentara, polisi, veteran, dan pegawai swasta (Setiyono and Chalmers, 2018, hlm. 141). Akan tetapi cakupan layanan mereka masih sangat 
terbatas. Sehingga pada masa awal reformasi, muncul gagasan penyediaan jaminan layanan kesehatan untuk masyarakat miskin dan tidak mampu, melalui skema Jaminan Kesehatan Masyarakat (Jamkesmas) di tingkat pusat dan Jaminan Kesehatan Daerah (Jamkesda) di tingkat daerah. Walaupun demikian, program dan skema-skema tersebut masih terfragmentasi, terbagi-bagi dalam berbagai macam instansi yang tidak terkoneksi satu sama lain. Besaran biaya asuransi kesehatan, standar mutu pelayanan, dan cakupan subsidi pembayaran menjadi sangat bervariasi dan sulit terkendali. Program-program tersebut juga dinilai kurang berhasil memberikan manfaat yang berarti kepada para penggunanya, karena jumlah pesertanya belum mencakup seluruh penduduk, jumlah nilai manfaat program kurang memadai, dan kurang baiknya tata kelola manajemen program tersebut.

Sejak masa awal reformasi tahun 2000, pemerintah mulai merencanakan pembuatan sistem jaminan kesehatan nasional yang terintegrasi. Bappenas ditugasi untuk menyusun tim yang mempersiapkan rencana ini. Sebagai usaha permulaan, pada tahun 2003, tim berhasil menyusun draft Undang-Undang Nomor 40 tentang Sistem Jaminan Sosial Nasional (SJSN) yang kemudian disahkan Dewan Perwakilan Rakyat (DPR) pada tahun 2004. Undang-Undang ini mengamanatkan bahwa jaminan sosial adalah sesuatu yang wajib tersedia bagi seluruh rakyat Indonesia, termasuk di dalamnya Jaminan Kesehatan Nasional (JKN) melalui suatu Badan Penyelenggara Jaminan Sosial (BPJS) yang diawasi oleh Dewan Jaminan Sosial Nasional (DJSN). Undang-Undang ini merupakan kebijakan baru di bidang jaminan sosial di Indonesia yang bertujuan untuk menggantikan dan mengintegrasikan program-program jaminan sosial yang ada sebelumnya seperti Askes, Asabri, dan Jamsostek.

Penyempurnaan dan pelaksanaan dari konsep jaminan sosial tersebut kemudian direalisasikan tujuh tahun kemudian melalui pembentukan badan penyelanggara teknis yang tertuang dalam Undang-Undang No. 24 Tahun 2011 tentang Badan Penyelenggara Jaminan Sosial, dimana BPJS ini terdiri atas BPJS Kesehatan dan BPJS Ketenagakerjaan. BPJS Kesehatan bertugas untuk melaksanakan program Jaminan Kesehatan Nasional (JKN) yang implementasinya dimulai pada tanggal 1 Januari tahun 2014. Secara operasional, pelaksanaan JKN dituangkan dalam berbagai Peraturan Pemerintah dan Peraturan Presiden, antara lain Peraturan Pemerintah No.101 Tahun 2012 tentang Penerima Bantuan Iuran (PBI), Peraturan Presiden No. 12 Tahun 2013 tentang Jaminan Kesehatan dan Peta Jalan JKN (Roadmap Jaminan Kesehatan Nasional), dan Peraturan Menteri Kesehatan RI Nomor 71 Tahun 2013 tentang Pelayanan Kesehatan pada Jaminan Kesehatan Nasional.

Konsep kebijakan Jaminan Kesehatan Nasional sesuai Undang-Undang Nomor 40 


\section{POLITIKA}

JURNAL ILMU POLITIK, Volume 9 Nomor 2, Oktober 2018

Tahun 2004 tentang Sistem Jaminan Sosial Nasional mengintegrasikan mekanisme bantuan social (social assistance) oleh negara ditujukan untuk penduduk yang kurang mampu, sehingga seluruh penduduk pada saatnya nanti akan menjadi peserta JKN. Pada prinsipnya, kepesertaan JKN menggunakan prinsip compulsory insurance sehingga bersifat wajib bagi seluruh penduduk Indonesia. Pelaksanaannya akan dilakukan secara bertahap.

Selain itu, dalam hal besarnya iuran atau premi, JKN menerapkan mekanisme asuransi sukarela (voluntary insurance) yang dibayar oleh peserta (atau bersama pemberi kerja) sesuai dengan tingkat risikonya dan keinginan jenis-jenis coverage-nya. Asuransi kesehatan ini diharapkan akan mengurangi risiko masyarakat dalam menanggung biaya kesehatan dari kantong sendiri out of pocket, yang seringkali jumlahnya sulit diprediksi dan seringkali membutuhkan biaya yang sangat besar. Melalui asuransi kesehatan sosial ini, peserta hanya membayar premi dengan besaran tetap, untuk menutup biaya layanan kesehatan yang mungkin timbul manakala mereka sakit. Hal ini dimungkinkan karena pembiayaan kesehatan ditanggung bersama secara gotong royong oleh keseluruhan peserta, sehingga tidak memberatkan rakyat secara individu.

Skema Jaminan Kesehatan Nasional ini memiliki beberapa keunggulan dibandingkan dengan asuransi komersial swasta. Misalnya, karena jumlah peserta terbatas, maka biaya premi asuransi komersial biasanya relatif lebih tinggi sehingga hanya terjangkau bagi sebagian kecil masyarakat. Selain itu, manfaat cakupan layanan (coverage) yang ditawarkan umumnya lebih sedikit. Sedangkan asuransi kesehatan sosial memiliki manfaat yang lebih komprehensif walaupun dengan biaya premi yang lebih terjangkau.

Lebih dari itu, asuransi kesehatan sosial menerapkan prinsip kendali biaya dan mutu, khususnya karena adanya pengawasan politik dari lembaga perwakilan. Itu berarti peserta bisa mendapatkan pelayanan bermutu memadai dengan biaya yang wajar dan terkendali, bukan sekedar didikte oleh unit pelayanan kesehatan seperti dokter atau rumah sakit. Karena terkelola dalam lingkup pemerintah, maka asuransi kesehatan sosial menjamin sustainabilitas (kepastian pembiayaan pelayanan kesehatan yang berkelanjutan) yang berkaitan dengan adanya kesesuaian besaran iuran dengan manfaat yang diberikan serta penambahan jumlah peserta sehat. Ada dukungan dari anggaran negara dan daerah.

Asuransi kesehatan sosial juga memiliki jangkauan portabilitas demografis yang luas, sehingga dapat digunakan di seluruh wilayah Indonesia. Dengan prinsip gotong-royong, maka dimungkinkan terjadinya subsidi silang antar peserta dengan tingkat premi yang berbeda 
sehingga dapat melindungi seluruh warga, karena kepesertaan asuransi kesehatan sosial/ JKN bersifat wajib.

\section{MEKANISME JAMINAN KESEHATAN NASIONAL}

Untuk mengatur pelayanan jaminan kesehatan, dibuat alur mekanisme agar tujuan dari adanya JKN dapat tercapai. Mekanisme ini biasanya mencakup pengaturan kepesertaan, ketentuan tarif iuran atau premi, jenis layanan kesehatan yang dicakup, mekanisme klaim, dan standarisasi unit layanan kesehatan.

\section{Kepesertaan}

Sesuai dengan ketentuan UU JKN, kepeserta BPJS Kesehatan meliputi setiap orang penduduk Indonesia, termasuk orang asing yang bekerja paling singkat 6 (enam) bulan di Indonesia, yang telah membayar iuran. Kategori peserta ini, meliputi Penerima Bantuan Iuran Jaminan Kesehatan (PBI), yakni fakir miskin dan orang tidak mampu, dengan penetapan peserta sesuai ketentuan peraturan perundang- undangan, dan Bukan Penerima Bantuan Iuran Jaminan Kesehatan (Non PBI).

Untuk kategori yang kedua ini terdiri dari tiga jenis. Pertama, Pekerja Penerima Upah dan anggota keluarganya, seperti Pegawai Negeri Sipil, Anggota TNI, anggota Polri, pejabat negara, pegawai pemerintah non pegawai negeri, pegawai swasta, dan pekerja lain yang menerima upah, termasuk WNA yang bekerja di Indonesia paling singkat 6 (enam) bulan. Kedua, Pekerja Bukan Penerima Upah dan anggota keluarganya, seperti pekerja di luar hubungan kerja atau Pekerja Mandiri, dan Pekerja Bukan Penerima Upah lain, termasuk Warga Negara Asing (WNA) yang bekerja di Indonesia paling singkat 6 (enam) bulan. Ketiga, Bukan pekerja dan anggota keluarganya, seperti investor; Pemberi Kerja, Penerima Pensiun (terdiri dari Pegawai Negeri Sipil yang berhenti dengan hak pensiun, anggota TNI dan anggota Polri yang berhenti dengan hak pensiun, Pejabat Negara yang berhenti dengan hak pensiun, janda, duda, atau anak yatim piatu dari penerima pensiun yang mendapat hak pensiun, penerima pensiun lain dan janda, duda, atau anak yatim piatu dari penerima pensiun lain yang mendapat hak pensiun, Veteran, Perintis Kemerdekaan, janda, duda, atau anak yatim piatu dari Veteran atau Perintis Kemerdekaan, Bukan Pekerja yang tidak termasuk kriteria tersebut yang mampu membayar iuran).

Kepesertaan tersebut mencakup perlindungan anggota keluarga yang ditanggung, pada masing-masing jenis kepesertaan diatur sebagai berikut:

1. Pekerja Penerima Upah, dimana keluarga inti meliputi istri/suami dan anak yang sah (anak kandung, anak tiri dan/atau anak angkat), sebanyak-banyaknya 5 (lima) orang. Anak kandung, anak tiri dari perkawinan yang sah, dan anak angkat yang sah, dengan 


\section{POLITIKA}

JURNAL ILMU POLITIK, Volume 9 Nomor 2, Oktober 2018

kriteria tidak atau belum pernah menikah atau tidak mempunyai penghasilan sendiri dan belum berusia 21 (dua puluh satu) tahun atau belum berusia 25 (dua puluh lima) tahun yang masih melanjutkan pendidikan formal.

2. Pekerja Bukan Penerima Upah dan Bukan Pekerja. Peserta dapat mengikutsertakan anggota keluarga yang diinginkan (tidak terbatas). Peserta dapat mengikutsertakan anggota keluarga tambahan, yang meliputi anak ke-4 dan seterusnya, ayah, ibu dan mertua. Peserta juga dapat mengikutsertakan anggota keluarga tambahan, yang meliputi kerabat lain seperti saudara kandung/ipar, pembantu atau asisten rumah tangga, dan sebagainya.

Untuk melaksanakan amanat universal coverage yang mencakup seluruh penduduk, pemerintah menetapkan rekrutmen kepesertaan Jaminan Kesehatan Nasional yang cukup ambisius yang harus selesai pada Januari 2019, walaupun pelaksanaannya dilakukan secara bertahap. Tahap pertama dimulai 1 Januari 2014, kepesertaannya paling sedikit mencakup peserta program asuransi publik (PBI dan Non-PBI Jaminan Kesehatan) yang sudah berjalan dengan skema lama, yakni Anggota TNI/PNS di lingkungan Kementerian Pertahanan dan anggota keluarganya; Anggota Polri/PNS di lingkungan Polri dan anggota keluarganya; peserta asuransi kesehatan PT Askes (Persero) beserta anggota keluarganya, serta peserta jaminan pemeliharaan kesehatan Jamsostek dan anggota keluarganya. Kemudian pada tahap kedua, kepsertaan akan meliputi seluruh penduduk yang belum masuk sebagai Peserta BPJS Kesehatan paling lambat pada tanggal 1 Januari 2019.

Pemerintah melalui Peraturan Presiden RI Nomor 2 tahun 2015 tentang RPJMN 2015-2019 memformulasikan indikator keberhasilan dari terselenggaranya Penguatan Jaminan Kesehatan Nasional (JKN)/Kartu Indonesia Sehat (KIS) berupa jumlah penduduk yang menjadi peserta Penerima Bantuan Iuran (PBI) melalui Jaminan Kesehatan Nasional $(\mathrm{JKN}) /$ Kartu Indonesia Sehat (KIS). Selanjutnya melalui Renstra Kementerian Kesehatan 2015-2019 juga diformulasikan Program Terselenggaranya Penguatan Jaminan Kesehatan Nasional (JKN)/Kartu Indonesia Sehat (KIS) yang menargetkan capaian jumlah penduduk yang menjadi peserta Penerima Bantuan Iuran (PBI) melalui Jaminan Kesehatan Nasional (JKN)/Kartu Indonesia Sehat (KIS) sebanyak 92.2 juta jiwa pada tahun 2019.

Sejalan dengan hal tersebut, terkait ketercapaian kepesertaan JKN tersebut, pemerintah memberi tugas kepada Kementerian Kesehatan sesuai dengan Peraturan Pemerintah Nomor 102 Tahun 2012 untuk mendaftarkan peserta PBI ke BPJS Kesehatan dari data terpadu yang 
telah ditetapkan oleh Kementerian Sosial dan membayarkan iuran sebesar jumlah yang didaftarkan. Sedangkan penambahan pendaftaran peserta PBI JKN/KIS dilakukan secara bertahap melalui SK Mensos RI Nomor 44B/HUK/2015, Nomor 58/HUK/2015, Nomor 128/HUK/2015, serta Nomor 132/HUK/2015. Selain itu, pemerintah juga mengeluarkan Instruksi Presiden Nomor 8 Tahun 2017 tentang Optimalisasi Pelaksanaan Program Jaminan Kesehatan Nasional. Inpres tersebut memerintahkan agar 11 kementerian/lembaga negara (yakni Kementrian Koordinator Bidang Pembangunan Manusia dan Kebudayaan (PMK), Kementerian Kesehatan, Kementerian Dalam Negeri, Kementerian Sosial, Kementerian BUMN, Kementerian Ketenagakerjaan, Kementerian Komunikasi dan Informatika, Jaksa Agung, Direksi BPJS Kesehatan, Gubernur, Bupati dan Walikota se Indonesia) mengambil langkah sesuai kewenangan masing-masing untuk menjamin keberlangsungan dan peningkatan kualitas program Jaminan Kesehatan Nasional-Kartu Indonesia Sehat (JKN-KIS). Langkah itu diantaranya adalah memastikan tidak ada lagi perusahaan 'bandel' yang tidak mau mendaftarkan pekerjanya sebagai peserta JKN-KIS, serta mendorong agar seluruh pemerintah daerah (pemda) segera mengintegrasikan Jaminan Kesehatan Daerah (Jamkesda) dengan JKN-KIS.

\section{Gambar 1. Target Peserta Penerima Bantuan Iuran (PBI) JKN/KIS}

Tahun 2014-2019

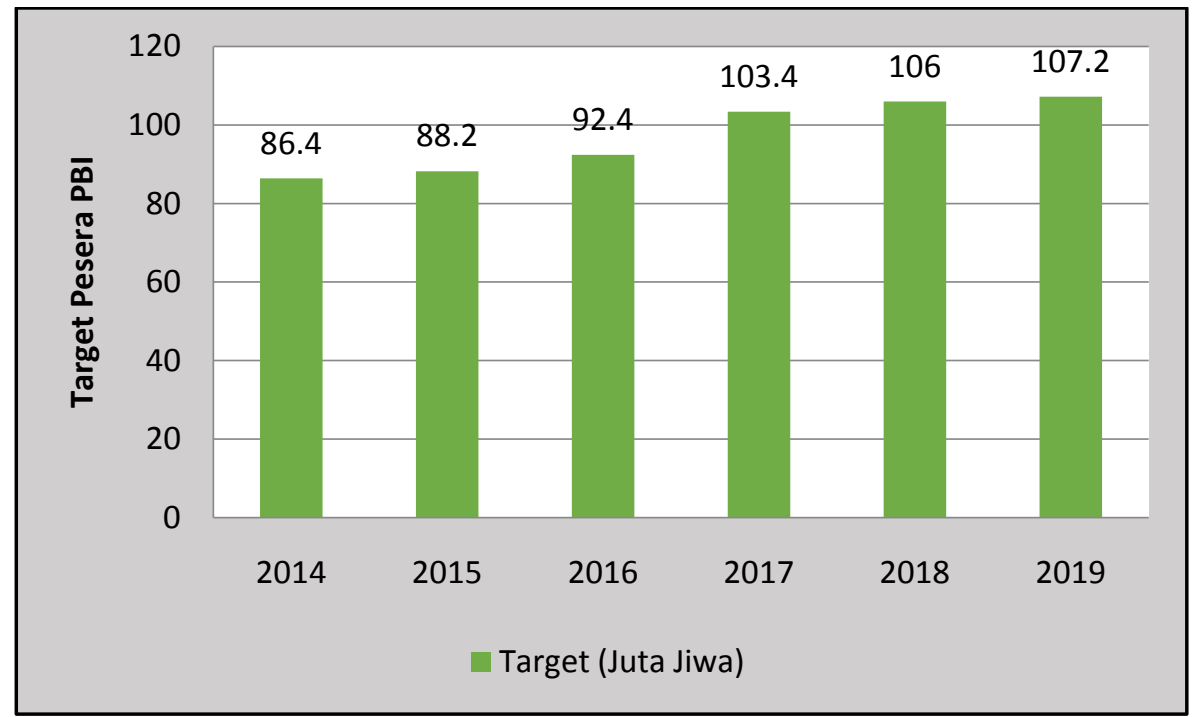

Sumber: Kementrian Kesehatan (2015) 


\section{POLITIKA}

JURNAL ILMU POLITIK, Volume 9 Nomor 2, Oktober 2018

Target tersebut memperlihatkan adanya kenaikan kepesertaan setiap tahun agar pada akhirnya JKN dapat mencover seluruh masyarakat dalam hal jaminan kesehatan pada tahun 2019 sehingga tercapai universal coverage. Realisasi pencapaian kepesertaan atau jumlah penduduk yang menjadi peserta Penerima Bantuan Iuran (PBI) melalui Jaminan Kesehatan Nasional (JKN)/Kartu Indonesia Sehat (KIS) adalah sebanyak 87.882.867 jiwa pada tahun 2015 dan menjadi 92,2 juta jiwa pada bulan April 2018. Dengan demikian, capaian kinerja indikator ini adalah sebesar 87 persen. Upaya pemenuhan capaian indikator tersebut pada tahun 2018 belum mampu sebesar 100 persen oleh Kementerian Kesehatan dikarenakan tidak terpenuhinya target jumlah peserta PBI yang ditetapkan sebanyak 106 juta jiwa oleh Kementerian Sosial.

Untuk memenuhi target kepesertaan, terutama dari unsur PBI, pemerintah membuat alur mekanisme pendaftaran dan pemberian bantuan dengan melibatkan berbagai instansi. Sesuai ketentuan dalam Peraturan Pemerintah Nomor 101 Tahun 2012 pasal 7, Kemensos diberi mandat untuk melakukan kriteria kelompok peserta PBI yang terdiri dari Penyandang Masalah Kesejahteraan Sosial (PMKS), yakni kelompok-kelompok sosial masyarakat bawah seperti kelompok masyarakat miskin, rentan miskin, serta tuna wisma serta para penghuni lapas dan rutan. Kemensos juga melakukan pengelolaan dan penetapan data masyarakat miskin peserta PBI dengan berkoordinasi bersama TNP2K (Tim Nasional Percepatan Penanggulangan Kemiskinan). Atas dasar Penetapan PBI oleh Kementrian Sosial tersebut, kemudian Kementrian Kesehatan mendaftarkan Jumlah peserta PBI sebagai peserta Program Jaminan Kesehatan serta membayar iurannya kepada BPJS Kesehatan. Hal tersebut digambarkan melalui tabel alur/mekanisme penugasan di bawah ini: 
Tabel 1. Alur dan Penugasan Role Player dalam

Pendataan Kepesertaan PBI JKN/KIS

\begin{tabular}{|c|c|}
\hline Instansi & Tugas \\
\hline Kemensos & $\begin{array}{l}\text { Menetapkan kriteria fakir miskin dan tidak mampu. } \\
\text { Melakukan pengelolaan data terpadu dan menetapkan peserta PBI } \\
\text { Jaminan Kesehatan. } \\
\text { Melakukan verifikasi dan Validasi data terpadu bersama TNP2K. }\end{array}$ \\
\hline Badan Pusat Statistik & Melakukan pendataan penduduk sesuai kriteria yang ditetapkan Kemensos \\
\hline 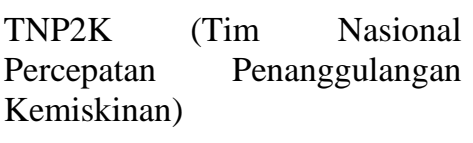 & Melakukan verifikasi dan Validasi data terpadu bersama Kemensos \\
\hline Kemenkes & Mendaftarkan peserta dan membayar iuran PBI Jaminan Kesehatan \\
\hline BPJS Kesehatan & $\begin{array}{l}\text { Menerima pendaftaran kepesertaan } \\
\text { Melakukan pengelolaan master file dan perubahan data identitas }\end{array}$ \\
\hline
\end{tabular}

Sumber: Peraturan Pemerintah Nomor 101 Tahun 2012

Sampai saat ini jumlah total keseluruhan peserta JKN dari semua komponen berdasarkan data BPJS Kesehatan (pada bulan Mei 2018) berjumlah 196,66 juta jiwa. Angka ini setara dengan 74 persen dari jumlah keseluruhan penduduk Indonesia yang diperkirakan telah mencapai 265 juta jiwa pada tahun 2018 (BPS 2018). Dari jumlah tersebut, lebih dari separuh peserta BPJS Kesehatan dibiayai pemerintah dari Anggaran Pendapatan dan Belanja Negara (APBN) maupun Anggaran Pendapatan dan Belanja Daerah (APBD). Dari total 176,74 juta peserta BPJS Kesehatan, sebanyak 92,3 juta (52 persen) merupakan penerima bantuan iuran (PBI) dari APBN dan 16,96 juta (9,59 persen) dari APBD. ${ }^{26}$ Dengan demikian, jumlah peserta BPJS Kesehatan yang menerima bantuan iuran negara (APBN dan APBD) mencapai 108,99 juta peserta atau lebih dari 61,67 persen. Sedangkan komposisi keseluruhan jumlah peserta JKN yang terdaftar sampai dengan bulan Mei 2018 adalah sebagai berikut:

${ }^{26}$ Detik.com, 2 Mei 2018, alamat:

https://finance.detik.com/berita-ekonomi-bisnis/d-4001072/hingga-april-2018-baru-92-juta-peserta-bpjs-yang-di $\underline{\text { bayarin-pemerintah }}$ 
JURNAL ILMU POLITIK, Volume 9 Nomor 2, Oktober 2018

Gambar 2. Jumlah Peserta Program Jaminan Kesehatan Nasional

Per Mei 2018

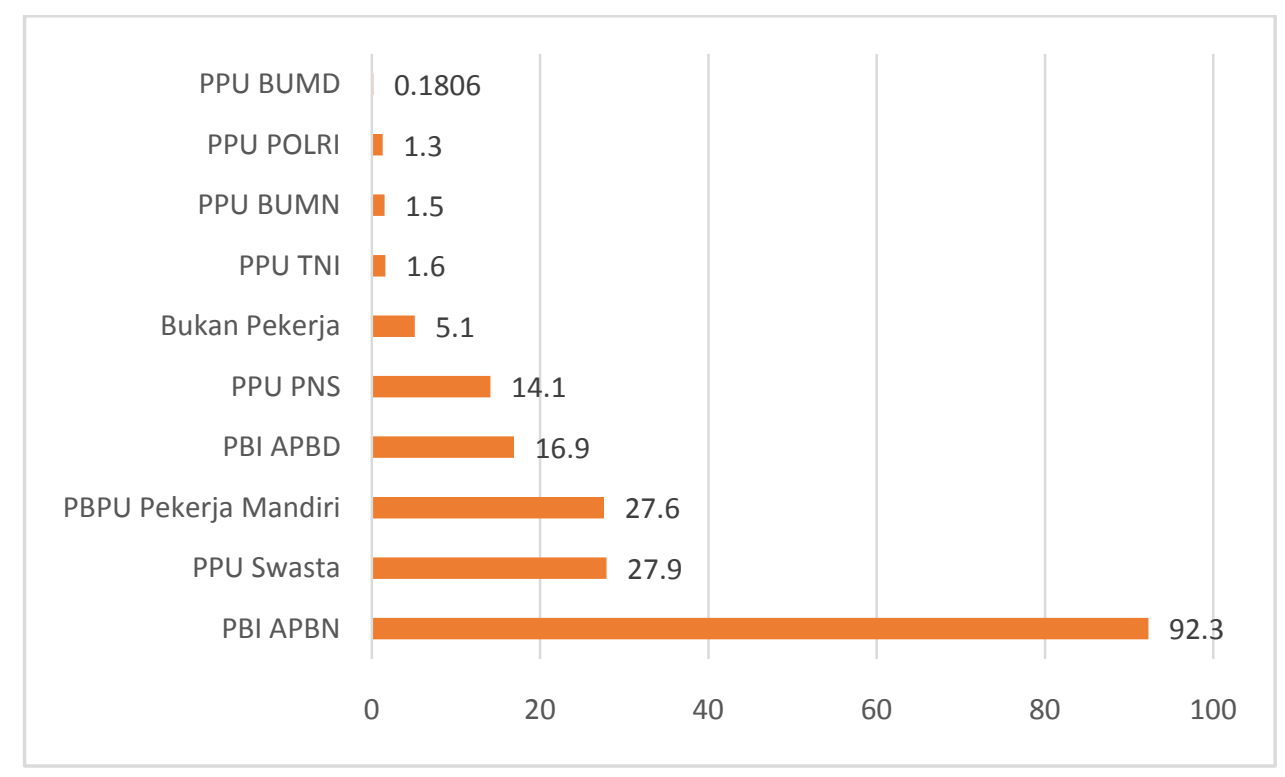

Sumber: BPJS Kesehatan RI (www.bpjs.go.id)

\section{Iuran / Premi peserta JKN}

Sebagaimana dikemukakan diatas, sistem jaminan kesehatan pada prinsipnya menggunakan mekanisme asuransi sosial, dimana seluruh pesertanya memberikan iuran untuk menanggung resiko bersama terhadap gangguan kesehatan yang dialami para pesertanya. Sesuai dengan pasal 16, Perpres No. 12/2013 tentang Jaminan Kesehatan, Iuran Jaminan Kesehatan merupakan sejumlah uang yang dibayarkan secara teratur baik oleh Peserta, Pemberi Kerja, dan/atau Pemerintah untuk program Jaminan Kesehatan. Dalam konteks ini, penentuan jumlah iuran harus disesuaikan dengan manfaat yang diberikan, serta penambahan jumlah peserta JKN sehingga tidak terjadi defisit bagi badan pengelola, dalam hal ini BPJS Kesehatan.

Pemerintah mengatur jumlah iuran yang disesuaikan setiap tahun untuk setiap peserta yang wajib dibayar berdasarkan persentase dari upah atau suatu jumlah nominal tertentu. Dalam konteks ini, untuk pembayaran premi dari peserta JKN dari unsur pekerja, maka pemberi kerja wajib memungut iuran dari pekerjanya, yang menjadi kewajibannya dan membayarkan iuran tersebut kepada Badan Penyelenggara Jaminan Sosial (BPJS) secara berkala. Dalam hal ini, pembayaran premi BPJS Kesehatan adalah termasuk bagian dari fasilitas yang wajib diberikan oleh perusahaan yang menanggung 4 persen dari upah, sedangkan pekerja menanggun 1 persen sisanya. Sedangkan iuran dari pengangguran, fakir 
miskin dan orang yang tidak mampu, ditanggung/dibayarkan oleh pemerintah. Ketentuan tentang jumlah iuran dan bentuk iuran menurut jenis peserta, dapat dilihat pada tabel berikut:

Tabel 2. Iuran Jaminan Kesehatan Nasional Tahun 2013

\begin{tabular}{|l|l|l|l|}
\hline \multicolumn{1}{|c|}{ Peserta } & Bentuk Iuran & \multicolumn{1}{c|}{ Besaran Iuran } & \multicolumn{1}{|c|}{ Keterangan } \\
\hline PBI & Nilai Nominal per jiwa & $\begin{array}{l}\text { Rp. 19.225 (2013) } \\
\text { Rp. 34.105 (2014) }\end{array}$ & Faskes Rawat Inap kelas 3 \\
\hline PNS/TNI/POLRI/ Pensiunan & 5\% dari gaji & $\begin{array}{l}2 \% \text { dari pekerja } \\
3 \% \text { dari pemberi kerja }\end{array}$ & $\begin{array}{l}\text { Faskes Rawat Inap kelas 1 } \\
\text { dan 2 }\end{array}$ \\
\hline $\begin{array}{l}\text { Pekerja Swasta atau Penerima } \\
\text { Upah Selain PNS dll }\end{array}$ & $\begin{array}{l}4,5 \% \text { sd. 5\% pendapata } \\
\text { (per keluarga) }\end{array}$ & $\begin{array}{l}\text { sd 30 Juni 2015: } \\
0,5 \% \text { dari pekerja } \\
4 \% \text { dari pemberi kerja }\end{array}$ & $\begin{array}{l}\text { Faskes Rawat Inap kelas 1 } \\
\text { dan 2 }\end{array}$ \\
& & $\begin{array}{l}\text { Per 1 Juli 2015: } \\
1 \% \text { dari pekerja } \\
4 \% \text { dari pemberi kerja }\end{array}$ & \\
\hline $\begin{array}{l}\text { Pekerja Bukan Penerima Upah } \\
\text { dan Bukan Pekerja }\end{array}$ & Nilai Nominal (per jiwa & $\begin{array}{l}1 . \text { Rp. 25.500 } \\
\text { 2. Rp. 42.500 } \\
\text { 3. Rp. 59.500 }\end{array}$ & $\begin{array}{l}\text { Faskes Rawat Inap kelas 1, } \\
\text { dan 3 }\end{array}$ \\
\hline
\end{tabular}

Sumber: Perubahan Peraturan Presiden Nomer 12 Tahun 2013; Permenkes 59 tahun

2014

\section{Skema Sistem Kolektif}

Sebagaimana dikemukakan diatas, sistem JKN memungkinkan adanya tanggung renteng terhadap resiko pembiayaan layanan kesehatan yang mahal melalui subsidi silang dalam program, antar kepesertaan dan antar generasi secara nasional. Selanjutnya sebagaimana prinsip standar jaminan sosial di banyak negara, maka JKN dalam pembayaran manfaat menggunakan sumber utama dari anggaran negara (pay-as-you-go) dengan skema kerjasama dalam pendanaan bersama antara perusahaan, tenaga kerja, dan pemerintah. Oleh karena itu, pemerintah perlu menyiapkan anggaran jaminan sosial untuk membantu kelompok yang tidak memiliki kemampuan bayar karena menganggur (tidak punya penghasilan), seperti pada saat timbulnya krisis ekonomi, pensiun, kecelakaan, sakit, maupun terkena wabah penyakit.

Pada tahun 2017, jumlah iuran Jaminan Kesehatan Nasional-Kartu Indonesia Sehat (JKN-KIS) yang dikelola BPJS Kesehatan adalah sebesar Rp. 74,25 triliun. Dari jumlah tersebut, total anggaran yang berasal dari APBN adalah 34 persen atau sebesar Rp. 25,3 triliun. Sedangkan sisanya adalah berasal dari kontribusi masyarakat dan pemerintah daerah (APBD). Jumlah dana ini meningkat dari tahun ke tahun, dan sejak berdiri tahun 2014, BPJS Kesehatan telah mendapatkan total iuran sebesar Rp. 234,06 triliun. 


\section{Gambar 3. Konsep Jaminan Kesehatan Nasional}

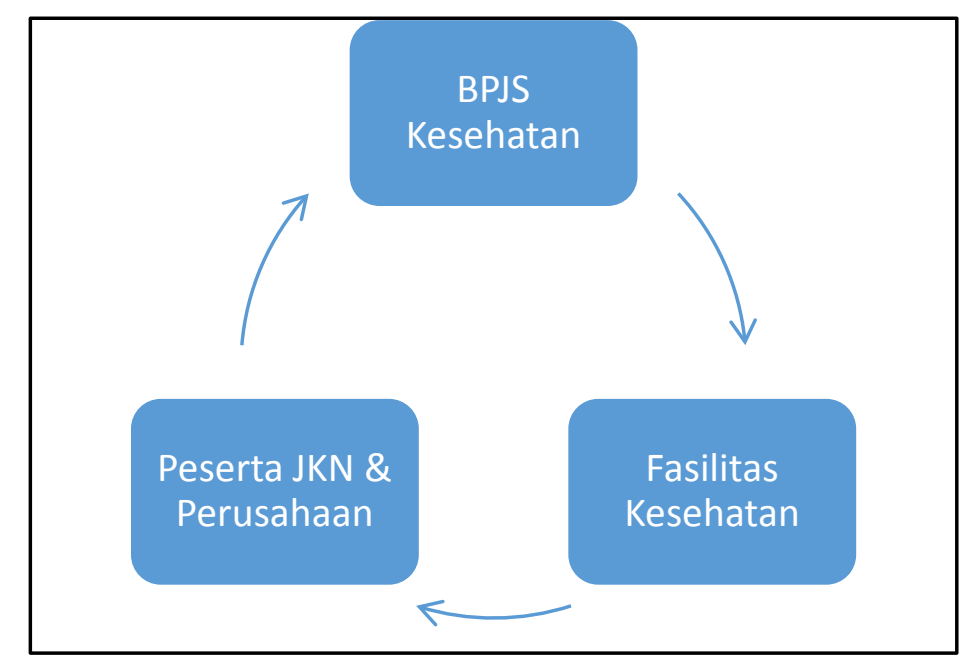

Sumber: BPJS Kesehatan RI (www.kesehatan.go.id)

Dalam konteks ini, JKN mengkonsep sinergitas antar berbagai macam lembaga terkait, khususnya tiga pilar, yakni: (1) Peserta JKN (dan Perusahaan yang membayarkan premi), (2) BPJS Kesehatan, serta (3) Fasilitas Kesehatan untuk mewujudkan jaminan sosial kesehatan yang memadai. Peserta JKN adalah mereka yang membayar kepesertaan kepada BPJS Kesehatan dalam bentuk premi atau iuran (bagi kelompok pekerja dibayarkan perusahaan sedangkan bagi kelompok yang tidak bekerja dibayarkan oleh negara). Kemudian BPJS Kesehatan menjalankan fungsi sebagai lembaga yang bertugas untuk melakukan pengumpulan-pengaturan resiko (risk pooling) dan mengatur distribusi pembayaran layanan kesehatan kepada penyelenggara layanan kesehatan. Sedangkan Fasilitas Kesehatan (seperti Rumah Sakit, Klinik, Puskesmas, Apotik) melakukan fungsi pelayanan kesehatan kepada peserta yang sudah membayar premi.

Adapun mekanisme atau prosedur pelayanan kesehatan diatur berdasarkan Peraturan Menteri Kesehatan nomor 71 tahun 2014 yang menggunakan sistem rujukan berjenjang. Sebagaimana diatur dalam pasal 14 ayat 1, maka peserta yang mengalami gangguan kesehatan sesuai dengan indikasi medis dapat berobat ke Faskes 1 (fasilitas kesehatan tingkat pertama) terlebih dahulu untuk mendapatkan jaminan kesehatan dari BPJS.

Peserta dapat memilih Faskes tingkat pertama mereka masing - masing pada saat awal pendaftaran, dan tercantum pada kartu peserta. Sehingga manakala mereka sakit bisa 


\section{POLITIKA}

JURNAL ILMU POLITIK, Volume 9 Nomor 2, Oktober 2018

langsung berobat ke faskes yang tertera pada kartu peserta yang mereka miliki. Kemudian Pasal 15 ayat (2) dan ayat (3) mengatur bahwa ketika pelayanan faskes tingkat pertama tidak dapat menangani pasien, baik itu karena keterbatasan tenaga medis atau alat medis, maka peserta dapat dirujuk/dialihkan ke Rumah Sakit sebagai fasilitas tingkat lanjutan. Sistem rujukan ini merupakan prosedur berobat atau prosedur pelayanan mutlak untuk mendapat jaminan pembayaran oleh BPJS. Ketentuan ini dikecualikan jika peserta dalam keadaan gawat darurat, mereka dapat langsung eminta layanan ke UGD Rumah Sakit yang sudah menjadi mitra BPJS Kesehatan.

\section{TANTANGAN KEBERLANJUTAN PROGRAM JKN/KIS}

Persoalan pokok yang dihadapi oleh program asuransi sosial nasional di berbagai negara adalah berkaitan dengan keseimbangan antara optimalisasi penyediaan manfaat dengan ketersediaan sumber dana. Bagaimanapun, keinginan untuk menyediakan pelayanan kesehatan yang adil bagi semua orang akan menuntut ketersediaan dana bagi lembaga pengelola semacam BPJS Kesehatan. Pertama, apakah besaran iuran yang ditetapkan pemerintah serta besarnya jumlah kepesertaan telah mencukupi untuk mengatasi biaya pengeluaran kolektif BPJS Kesehatan (baik biaya perawatan maupun operasional). Kedua, apakah jenis-jenis pelayanan kesehatan yang dibiayai oleh JKN berkorelasi dengan perhitungan besaran iuran itu sendiri. Dan ketiga, apakah iuran kepesertaan non-subsidi akan mampu mensubsidi silang gap besaran bantuan pemerintah melalui APBN (yang biasanya berjumlah minimum).

Hal-hal tersebut sangat krusial untuk didiskusikan dan diselesaikan bila kita ingin menjaga keberlangsungan pelayanan dan sistem JKN. Mismatch antara iuran BPJS dan pembiayaan klaim harus diatasi, karena rasio klaim selalu diatas 100 persen dari jumlah iuran. Tidak mungkin kita menetapkan besaran iuran, misalnya, tanpa memperhitungkan implikasi terhadap manfaat jaminan bagi peserta yang harus ditanggung BPJS. Bagaimanapun, dalam prinsip gotong-royong harus memperhitungkan indeks subsidi silang antara peserta yang sakit dan yang sehat. Pengobatan satu pasien dengan sakit tertentu akan membutuhkan sekian puluh atau bahkan ratus orang peserta sehat dengan jumlah tarif tertentu. Catatan laporan keuangan tahunan BPJS Kesehatan menunjukkan defisit 


\section{POLITIKA}

JURNAL ILMU POLITIK, Volume 9 Nomor 2, Oktober 2018

masing-masing sebesar Rp 3,8 Triliun pada tahun 2014, Rp 5,9 Triliun (2015), Rp 9,7 Triliun (2016), 10 Triliun (2017), dan diperkirakan 16,2 Triliun (2018). ${ }^{27}$

Defisit yang dialami BPJS Kesehatan memiliki konsekuensi berupa mundurnya jadwal pembayaran klaim asuransi terhadap fasilitas kesehatan mitra. Pembayaran invoice seringkali dekeluhkan mundur selama ber-bulan-bulan. ${ }^{28}$ Hal ini pada akhirnya mengganggu proses bisnis pada mitra BPJS, terutama lembaga/rumah sakit swasta yang mengalami berbagai kesulitas seperti tersendatnya pembayaran kepada tenaga kerja, dokter dan spesialis yang berpraktik, maupun untuk memenuhi kewajiban pihak ketiga seperti jasa laboratorium, farmasi dan obat-obatan.

Beberapa rumah sakit bahkan diberitakan terancam bangkrut dan akan menutup usaha mereka akibat tagihan yang lama tidak terbayar oleh BPJS Kesehatan. Bila hal ini tidak segera ditanggulangi, maka dipastikan sistem layanan kesehatan di Indonesia secara keseluruhan akan terganggu.

Selain itu, tantangan yang dihadapi JKN juga berkaitan dengan adanya variasi standar tarif pelayanan kesehatan yang berbeda antar rumah sakit atau fasilitas kesehatan untuk satu tindakan media yang sama. Hasil wawancara dengan pejabat BPJS Kesehatan, misalnya, mengemukakan bahwa untuk tindakan medis operasi jantung, variasi jumlah biayanya bisa lebih dari lima macam tarif. ${ }^{29}$ Tanpa kewenangan melakukan intervensi dalam penentuan tarif, BPJS rentan menghadapi ketidakpastian untuk menentukan pengeluaran. Hasilnya, BPJS mengalami kesulitan dalam pengendalian biaya dan mutu layanan.

Akibatnya, manakala masyarakat mengeluhkan ketidakpuasan dalam pelayanan, BPJS tidak dapat meresponnya secara langsung. Pengendali mutu apalagi penentu biaya adalah Kementrian Kesehatan, sementara hubungan BPJS Kesehatan dan Faskes hanyalah pembeli jasa layanan yang secara pasif harus membayar tagihan asuransi jaminan kesehatan saja (lihat Trisnantoro, dkk, 2016).

Tantangan selanjutnya adalah berkaitan dengan distribusi keberadaan fasilitas kesehatan yang tidak merata di seluruh Indonesia. Sampai Januari 2018, terdapat fasilitas kesehatan yang menjadi mitra BPJS sebanyak 25.738 yang tersebar di seluruh Indonesia (lihat gambar

${ }^{27}$ Detik.com, 1 Agustus 2018, alamat: https://news.detik.com/kolom/d-4144570/di-balik-defisit-bpjs-kesehatan

${ }^{28}$ Tempo, 13 Februari 2018, alamat: https://bisnis.tempo.co/read/1060426/rs-swasta-keluhkan-pembayaran-klaim-bpjs-kesehatan-sering-telat/full\&vi $\underline{\mathrm{ew}=\mathrm{ok}}$

Wawancara 28 Juli 2017. 
4). Akan tetapi fasilitas dan SDM mereka tidak memiliki standar yang sama. Dokter spesialis, misalnya, hanya terkonsentrasi di beberapa rumah sakit di kota-kota besar, sementara sebagian besar rumah sakit lain, terutama di daerah, tidak memiliki dokter spesialis yang cukup (lihat Meliala, 2014).

Disparitas ini dapat menyebabkan adanya rasa ketidakadilan bagi peserta BPJS Kesehatan. Hal ini karena pada satu sisi peserta harus membayar jumlah besar iuran premi yang sama, akan tetapi mereka harus menerima akses terhadap fasilitas berbeda-beda dari setiap daerah. Implikasi dari persoalan ini terlihat misalnya dari perbedaan masa tunggu operasi, profesionalitas tenaga medis, dan fasilitas kelengkapan peralatan lain yang sangat bervariasi dari satu daerah ke daerah lain. 30

\section{Gambar 4. Provider Fasilitas Kesehatan yang terdaftar BPJS Kesehatan}

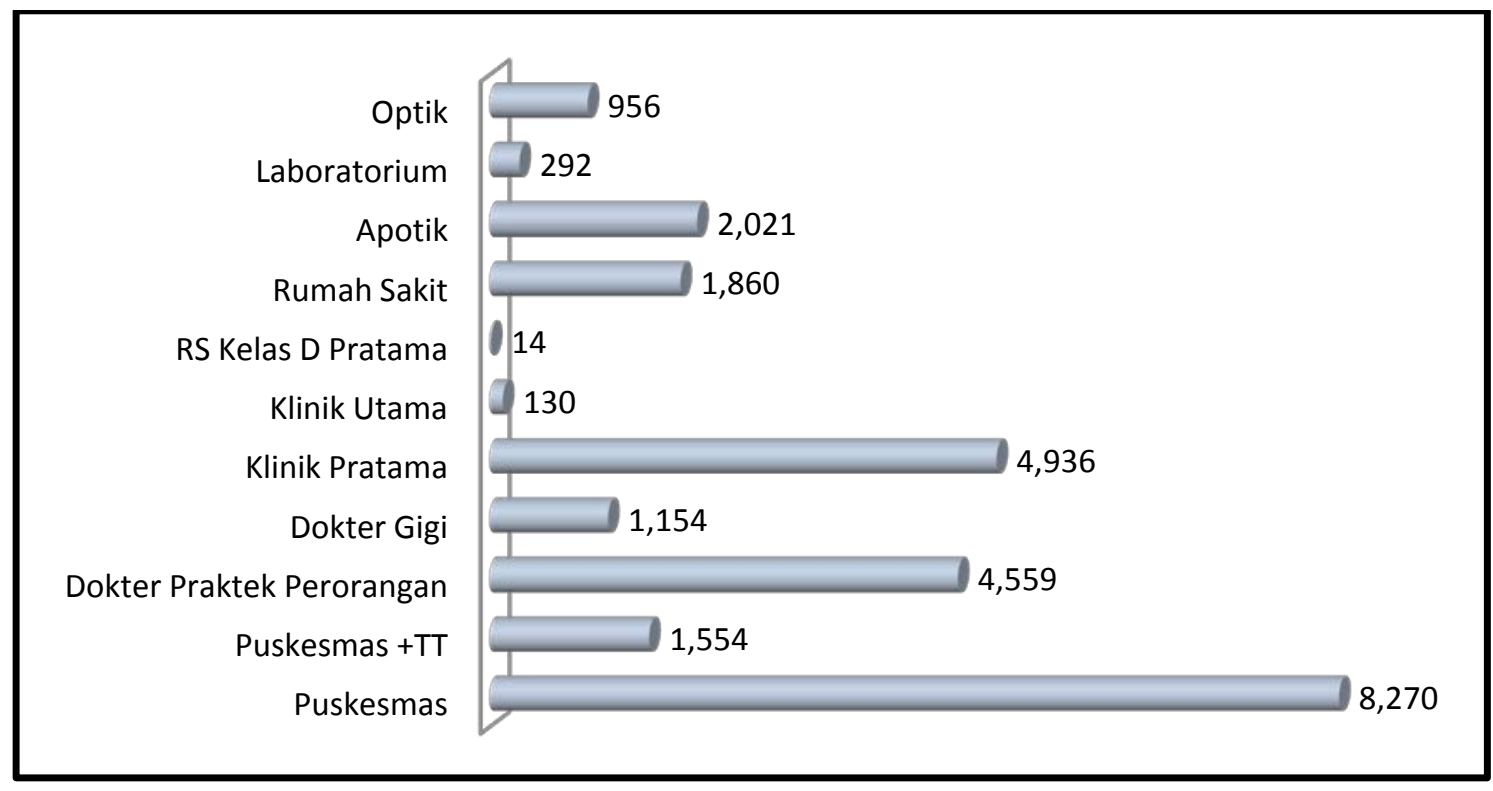

Sumber: BPJS Kesehatan RI (www.kesehatan.go.id)

\section{PERLUNYA REVITALISASI KEBIJAKAN}

Persoalan defisit yang dihadapi BPJS dalam pelaksanaan Jaminan Kesehatan ini menjelaskan ketimpangan antara benefit yang ditargetkan dan biaya yang harus dibayar oleh anggaran negara dan dana kepesertaan masyarakat yang tidak signifikan. Merupakan realita bahwa sebagian besar (61,59 peserta) jumlah peserta JKN adalah merupakan penerima bantuan iuran (PBI), yaitu sebanyak 92,3 juta orang (52 persen) disubsidi APBN dan 16,96

\footnotetext{
${ }^{30}$ Wawancara 28 Juli 2017.
} 


\section{POLITIKA}

JURNAL ILMU POLITIK, Volume 9 Nomor 2, Oktober 2018

juta orang (9,59 persen) disubsidi APBD. Disini jelas ada ketimpangan dan ketergantungan sebagian peserta yang tidak bekerja (dan disubsidi pemerintah) terhadap peserta lain yang bekerja (tidak disubsidi pemerintah). Hal ini merupakan fenomena yang tidak sehat, dimana sebagian kecil orang (yakni 38,41 persen) harus menanggung beban sebagian besar orang lain (yakni 61,59 persen). Idealnya, sebagian besar orang menanggung jumlah yang lebih sedikit. Persoalan ini diperparah oleh adanya kecenderungan sebagian masyarakat yang tidak taat membayar premi secara rutin tiap bulan, sehingga defisit juga disebabkan karena kolektifitas iuran rendah sementara pembiayaan tinggi.

Dalam konteks ini, maka pemerintah perlu mengembangkan lapangan kerja yang layak yang bisa menjangkau seluruh penduduk (full employment), sehingga semakin kecil subsidi yang harus dikeluarkan pemerintah. Bila semua penduduk bekerja maka mereka dapat membayar premi tanpa harus bergantung pada subsidi pemerintah. Harus dicatat bahwa pengalaman negara maju seperti Jerman, Inggris, dan Perancis, pada saat awal membangun sistem welfare state, selalu diikuti oleh kebijakan full employment sehingga pengangguran dapat ditekan dan pengeluaran sosial pemerintah dapat diperkecil (lihat Lindbeck, 1997).

Pemerintah juga perlu mengatasi ketidaksinkronan dalam penetapan teknis iuran dan kepesertaan antar lembaga. Pengelolaan JKN selama ini memisahkan antara manajemen dengan pengelolaan dana. Pada satu sisi penetapan dana dan kepesertaan dilakukan pemerintah (dalam hal ini dilakukan oleh Kementrian Sosial, Kementrian Kesehatan dan Kementrian Keuangan), sementara BPJS sebagai lembaga teknis manajerial hanya tunduk pada ketentuan pemerintah belaka. Hal ini merupakan tata kelola yang tidak rasional, mengingat BPJS harus menanggung defisit manakala pemerintah salah hitung. Artinya, resiko kesulitan likuiditas diletakkan dalam tanggungjawab lembaga teknis (dalam hal ini BPJS Kesehatan sebagai BUMN Persero yang tunduk dengan UU No.40/2007 tentang Perseroan Terbatas). Padahal, dengan alasan politik, pemerintah tentu akan selalu mengusahakan agar anggaran iuran dapat ditekan seminimal mungkin, sementara program ini harus tetap dijalankan.

BPJS Kesehatan seharusnya dilibatkan dalam hal-hal yang memiliki pengaruh terhadap teknis penyelenggaraan seperti dalam mekanisme perancangan tarif dan sosialisasi rekrutmen kepesertaan untuk memenuhi target universal coverage pada tahun 2019. Harus diingat bahwa dalam sistem JKN ini berbeda dengan model asuransi swasta karena tidak memberlakukan sistem reviu terhadap kondisi kesehatan untuk menaikan premi. Akibatnya manakala semua orang harus jadi peserta, maka dengan iuran minim mereka harus dapat menerima manfaat 
yang sesuai dengan standar pemerintah. Realitas saat inilah yang menyebabkan defisit dana JKN yang ditnggung BPJS Kesehatan. Padahal menurut Undang-Undang No. 24/2011, defisit tersebut seharusnya ditanggung dan dibebankan pada pemerintah.

\section{PENUTUP}

Banyak pekerjaan rumah yang masih harus dibereskan untuk menyempurnakan sistem Jaminan Kesehatan Nasional kita. Sesuai UU No. 40/2004 dan No. 24 Tahun 2011, pemerintah seharusnya fokus untuk berfungsi sebagai regulator dan fasilitator dalam penyelenggaraan JKN. Oleh karena itu, teknis operasional pelaksanaan JKN harusnya menjadi kewenangan BPJS, agar mengelola penyelenggaraan sistem jaminan sosial yang didanai sendiri oleh masyarakat secara sehat dan profesional. Disamping itu, sesuai pasal 28-h dan pasal 34 UUD 1945, maka pemerintah harus mengambil tanggung jawab dalam upaya pemusatan resiko (risk of pooling) untuk distribusi yang adil bagi seluruh warga negara, sehingga tidak begitu saja melepas tanggung jawab manakala BPJS mengalami defisit. Selanjutnya, upaya dalam mewujudkan universal coverage juga perlu diikuti dengan usaha untuk menyediakan lapangan kerja bagi seluruh penduduk sehingga mereka lebih mandiri dalam membayar premi daripada bergantung pada subsidi negara. Tanpa upaya-upaya tersebut, maka mimpi untuk mewujudkan kesejahteraan yang paripurna bagi rakyat Indonesia akan sulit terwujud.

\section{DAFTAR PUSTAKA}

BPJS Kesehatan 2017, Peserta program JKN per 6 January 2017, BPJS Indonesia, Jakarta (https://bpjs-kesehatan.go.id/bpjs/index.php/jumlahPeserta, diambil 13 January 2017)

CCUBHCS (Committee on the Consequences of Uninsurance Board on Health Care Services) 2001, Coverage matters: Insurance and health care, National Academy Press, Washington, DC

Fos, PJ \& Fine, DJ 2000, Designing health care for populations: Applied epidemiology in health care administration, Jossey-Bass, San Francisco

Gottret, P \& Schieber, G 2006, Health financing revisited: A practioner's guide, The World Bank, Washingthon DC

Jonas, S, Goldsteen, R and Goldsteen, K 2007, An introduction to the U.S. health care system, 6th ed, Springer Publishing Company, New York

Kementrian Kesehatan 2015, Laporan Akuntabilitas Kinerja Pemerintah (LAKIP) Kementrian Kesehatan, Kementrian Kesehatan, Jakarta

Lindbeck, A 1997, "Full Employment and the Welfare State," Seminar Papers 617, Stockholm University, Institute for International Economic Studies

Meliala, A 2014, "Distribution and engagement of specialist doctors in public hospitals in Indonesia", BMC Public Health, Vol. 14, Supplement 1, hlm. 10-15 


\section{POLITIKA}

JURNAL ILMU POLITIK, Volume 9 Nomor 2, Oktober 2018

Mukti, AG 2009, Pengembangan jaminan pembiayaan kesehatan dalam Konteks kesejahteraan minimum: Studi kasus Di Indonesia, makalah dipaparkan dalam Seminar Nasional "Kesejahteraan Sosial Minimum” dalam Rangka Dies Natalies Ke-60 UGM

Murti, B 2010, Strategi untuk mencapai cakupan universal pelayanan kesehatan di Indonesia, disampaikan pada Temu Ilmiah Reuni Akbar FK-UNS, di Surakarta, 27 November

OECD 2014, "Health indicators: Hospital care", dalam OECD, Society at a glance: Asia/Pacific, Organisation for Economic Co-operation and Development, Paris

Setiyono, B and Chalmers, I 2018, "Labour protection policy in a Third World Economy: The case of Indonesia", Development and Society, Vol. 47, No. 1, pp. 139-158

Trisnantoro, L, dkk 2016, "A critical analysis of selected healthcare purchasing mechanisms in Indonesia", dalam A Honda, D McIntrye, K Hanson, \& V Tangcharoensathien (Eds.), Strategic purchasing in China, Indonesia and the Philippines (Vol. Comparative Country Studies, Vol. 2 No. 1), World Health Organization, Geneva

WHO 2003, Social Health Insurance, a Report of a Regional Expert Group Meeting New Delhi, India, 13-15 March.

WHO 2017, "The Republic of Indonesia health system review", Health systems in transition, Vol. 7, No. 1. 